\title{
Research
}

\section{Designing Conservation Corridors in Production Landscapes: Assessment Methods, Implementation Issues, and Lessons Learned}

\author{
$\underline{\text { Amanda T. Lombard }}^{1,2}$, Richard M. Cowling ${ }^{1,2}$, Jan H.J. Vlok $^{2}$, and Christo Fabricius $^{2}$
}

\begin{abstract}
Designing broad-scale conservation corridors has become increasingly common as a way of conducting an assessment for achieving targets for the representation and persistence of nature. However, since many of these corridors must traverse agricultural and other production landscapes, planning and implementation are not trivial tasks. Most approaches to conservation assessments in the dynamic world of production landscapes are data-intensive and analytically complex. However, in the real world, donor and other external requirements impose time and budget constraints, and dictate strong stakeholder involvement in the entire planning process. In order to accommodate this, assessments must be rapid, cheap, and the approach and products must be comprehensible and acceptable to stakeholders. Here we describe such an assessment aimed at identifying and implementing a network of conservation corridors in the Gouritz Initiative project domain of South Africa's Cape Floristic Region hotspot. We used empirical data and expert knowledge to identify a corridor network hypothesized to sustain key ecological and evolutionary processes. We also consulted experts to provide a spatially explicit assessment of the opportunity costs of conservation associated with agriculture, the predominant land use in the region. We used these products to identify categories of land requiring different actions and instruments to achieve conservation goals, thereby moving from the "where" to the "how" of conservation. This information was then fed into the collaborative strategy development process for the Gouritz Initiative. Our discussion emphasizes the lessons that we learnt from undertaking this assessment, particularly lessons regarding the implementation of the planning products. We conclude that at the outset of any planning project, a consensus on the vision must be achieved, a detailed social assessment of appropriate institutions must be undertaken, and a learning organization that practices adaptive comanagement should be established. These institutional and governance requirements are fundamental to successful implementation of conservation-planning products.
\end{abstract}

Key Words: biodiversity processes; conservation corridors; conservation planning; expert knowledge; Gouritz Initiative; implementation; production landscapes

\section{INTRODUCTION}

During the past two decades, a great deal of effort has gone into identifying priority areas for conservation action, but much less effort has been expended on identifying which actions are appropriate where (Knight et al. 2006b, Wilson et al. 2007). Acquisition of land for strict reservation is not a feasible conservation strategy in most cases (Miller and Hobbs 2002, Rosenzweig 2003), which exacerbates this problem. Indeed, for many parts of the world, particularly in production landscapes, the only realistic conservation strategy is to attempt to achieve land use practices that are compatible with the maintenance of biodiversity patterns and processes in the long term (Redford and Richter 1999, Cowling et al. 2002, Orr 2002).

In a similar vein, most conservation assessment research has focused on targeting the patterns of nature, principally species and land classes, rather than the processes that sustain and generate it (Balmford et al. 1998, Cowling et al. 1999, Pressey et al. 2007). However, it is reasonable to assume that conservation plans underpinned by the achievement of broad-scale process targets, for example, migratory corridors for plants and animals, are more likely to ensure the long term 
persistence of wild nature than plans that are based entirely on representing pattern features alone (Chetkiewicz et al. 2006).

Planning for processes in the complex and dynamic world of production landscapes is the most commonly encountered situation but also presents the most difficulties and is the least researched (Pressey et al. 2007). Assembling data on processes and their spatial surrogates, and on the vast array of relevant socioeconomic factors, is no trivial task (Cowling and Pressey 2003). It is also not trivial to implement routines to identify priority areas and corresponding actions, and to schedule these actions in such a way as to minimize loss of priority habitat. Some recent research has made substantial advances on planning in dynamic landscapes (Costello and Polasky 2004, Meir et al. 2004, Pressey et al. 2004, Polasky et al. 2005, Wilson et al. 2005). However, the approaches are often very complex, data intensive, and not necessarily comprehensible to the land managers and other stakeholders tasked with implementing the outcomes of the plan (Barthel et al. 2005, Hein et al. 2006).

One way of overcoming many of these constraints is to use expert knowledge. Local experts can contribute large amounts of information on biological and socioeconomic phenomena that would be hugely expensive and time-consuming to assemble in a more formal way (e.g., BojórquezTapia et al. 2003, Martin et al. 2005, Chalmers and Fabricius 2007). Local knowledge is often verbally transferred from one generation to another, which contributes long term information that would be very expensive, if not impossible, to acquire through conventional scientific methods (Agrawal and Chhatre 2006). Also, involving local experts in the assessment phase of a conservation planning process assists greatly in achieving their endorsement of the process, and the prospects for effective implementation are greatly enhanced if these experts are associated with agencies responsible for implementing the planning outcomes (Olivieri et al. 1995, Hannah et al. 1998, Dinerstein et al. 2000, Knight et al. 2006b). Multiscale adaptive governance is thus promoted, which leads to resilient institutional arrangements, all keys to the management of common pool resources such as biodiversity (Libel et al. 2006). Social learning takes place when participants share information and question their assumptions, leading to more sustainable solutions and greater awareness of challenges and opportunities (Bawden et al. 2007). However, local knowledge may be biased by experience and values, as has been pointed out on numerous occasions (Kress et al. 1998, Maddock and Samways 2000, Cowling et al. 2003b). Other key challenges associated with local knowledge are its fine-grained resolution and local scope. Scientific knowledge is, however, not immune to similar problems (Fabricius et al. 2006).

Here we report on an assessment aimed at designing conservation corridors for the Gouritz area of South Africa's Cape Floristic Region. The assessment was commissioned by the provincial conservation agency, CapeNature, with the intention of delivering products that could be used to develop a conservation strategy for the region, in collaboration with stakeholders, under the umbrella of CapeNature's Gouritz Initiative (GI) project (htt p://www.gouritz.com). It was made clear at the outset that the landscape management model for the project was not one of land purchase for the expansion of the formal protected area system; instead the emphasis was on engaging land owners in stewardship programs that did not disrupt their aspirations to receive economic returns from the use of their land. Such models are common elsewhere, e.g., biosphere reserves (Olsson et al. 2007), and International Union for Conservation of Nature (IUCN) Category V and VI protected areas (http:// www.iucn.org; Borrini-Feyerabend 1997).

Our assessment and planning products were guided by an operational model (Fig. 1) previously developed by Knight et al. (2006 $a$ ) and expanded by Cowling et al. (2008). We believe that if a conservation planning process misses any of the steps within this model, it will fail to produce useruseful products and will fall short of achieving implementation goals (Pierce et al. 2005, Knight et al. 2006b).

This project was funded by the Critical Ecosystem Partnership Fund (CEPF) through the Cape Action for People and the Environment Project (C.A.P.E.; http://www.capeaction.org.za). As with most donor-driven projects, time and funding were in short supply, six months and $\$ 43,000$, respectively. Consequently, we used existing vegetation and land use data, and experts from land management agencies and academia to identify a network of conservation corridors that would accommodate the biological processes necessary for the maintenance of wild nature in the planning domain. We also used 
Fig. 1. An operational model for mainstreaming conservation planning products for implementation (after Knight et al. 2006a, Cowling et al. 2008).

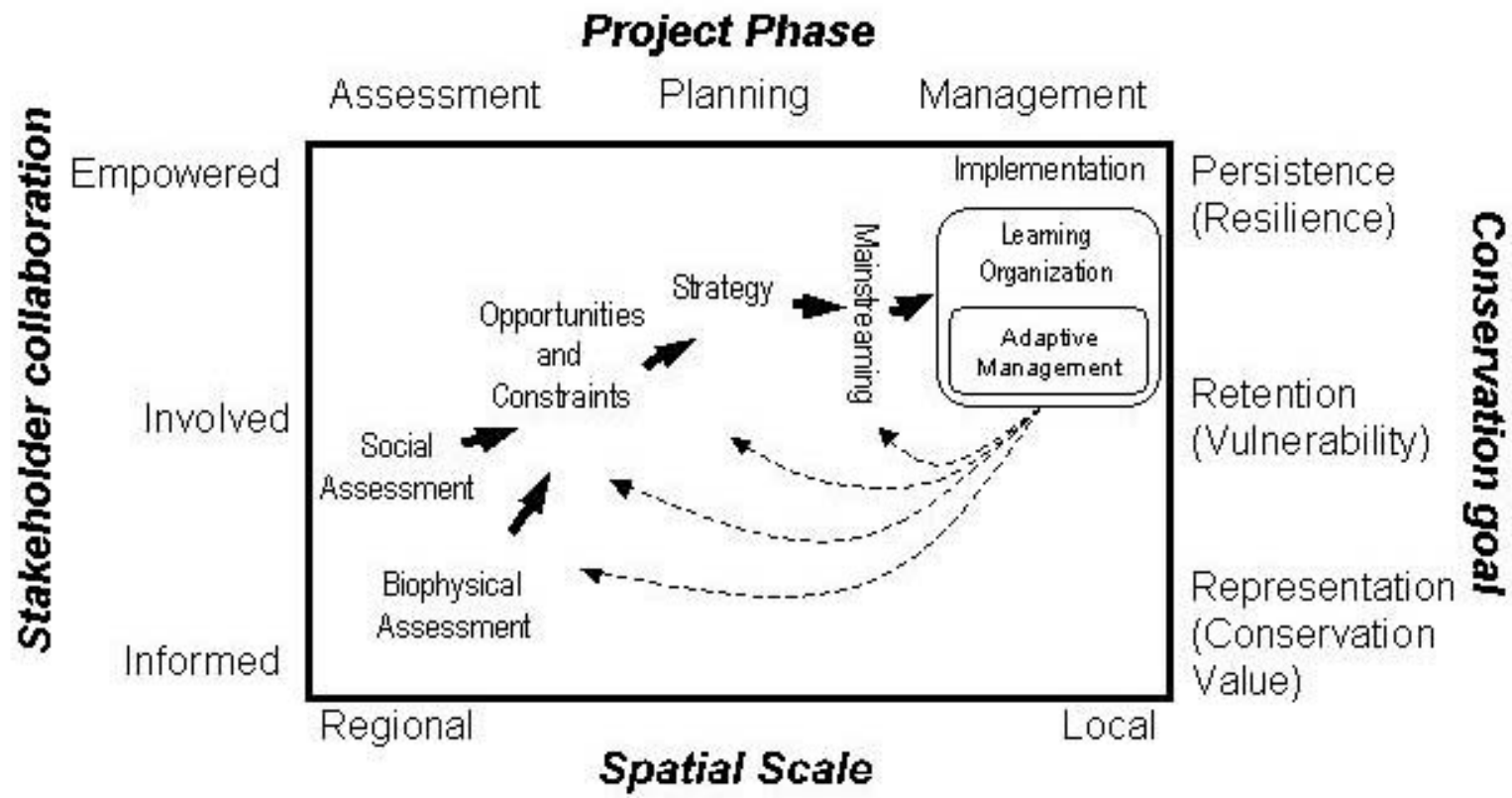

experts to provide a spatially explicit assessment of the opportunity costs of conservation associated with agriculture, the predominant land use in the region. We used these products to identify categories of land requiring different actions and instruments to achieve conservation goals. This information was then fed into the collaborative strategy development process for the Gouritz region. The discussion emphasizes the lessons that we learnt from undertaking this assessment, lessons that we believe are highly relevant for the costeffective identification and implementation of conservation corridors in production landscapes.

\section{METHODS}

\section{Participatory process}

During the project, science-based stakeholder dialogues (Welp et al. 2006) were used to consult with stakeholders, who served as both information providers and reviewers. Ecological experts represented all major biological taxa, as well as the different ecosystems within the planning domain. Research and management staff of all local conservation agencies and resource agencies, i.e., water, farming, forestry, and tourism, were involved, as were planners from local government structures. Individuals were chosen based on their local knowledge, their seniority within their organization, their interest in the GI, and their availability to attend workshops. Our independent consultancy team facilitated the workshops. We attempted to maximize information quality through refinement by producing reports after each workshop and circulating them to participants for comment. All comments were then worked into revised documents that were compiled and released as a draft report to the implementing agency. All comments from the draft report were then fed into the final report, released two months later. At this point, an open forum was established, the GI Forum, where all scientific results were presented to 
members of the public and other affected parties for comment. These meetings remain well attended by interested and affected parties who welcome the information sharing process and the opportunity to comment on the conclusions of researchers.

\section{Planning domain}

The study area falls within the central part of the Cape Floristic Region hotspot, and much of the area was identified as a priority for the conservation of both biodiversity pattern, e.g., species occurrences, and process, e.g., migration corridors, in an earlier, broad-scale conservation plan for this hotspot (Cowling et al. 2003a). The area comprises three major topo-climatic regions: a coastal plain (0-350 $\mathrm{m})$, the Cape Folded Belt comprising two east-west parallel mountain ranges $(500-2000 \mathrm{~m})$, and the Little Karoo Basin (200-600 m) between the mountain ranges (Fig. 2). Rainfall is low: $<400 \mathrm{~mm}$ per annum in the Little Karoo; 300-600 mm on the coastal plain; and up to $1700 \mathrm{~mm}$ in the mountains.

The coastal plain supports fynbos and strandveld vegetation (Mucina and Rutherford 2006). Along the coast, economic activity is dominated by resort development, recreational, nature-based land use, pasture-raised livestock farming, and indigenous vegetation harvesting, e.g., thatch and flowers. Over the last century, large areas have become invaded by alien trees, predominantly Acacia cyclops. Heavier soils support mainly rain-fed agriculture based on cereals and pasture. The rugged mountain landscapes comprise shallow, sandy, and highly infertile soils, unsuitable for cultivation or grazing. The vegetation includes a diversity of species- and endemic-rich fynbos types. Although much of the less rugged foothills have been cleared for agriculture, the intact upland landscapes are largely state owned and managed for nature conservation and water production. The Little Karoo Basin is a semiarid landscape, broken by koppies and strewn with gravel. The predominant vegetation is succulent karoo on the plains, and subtropical thicket and renosterveld on the koppies (Mucina and Rutherford 2006). Irrigated agriculture is restricted to riparian areas with access to perennial streams. The area is a major centre of ostrich production. These, and other livestock, have caused extensive degradation of the natural vegetation (Thompson et al. 2009).

We delineated the GI planning domain with an area of $32,693 \mathrm{~km}^{2}$ (Fig. 2) by integrating two spatial products. The first was the area identified by the CAPE Project (Cowling et al. 2003a) as the core for a proposed Gouritz Mega Reserve. The second product was the compilation of all the important areas delineated on 1:250,000 topographic map sheets at expert workshops at which conservation managers, aquatic biologists, botanists, entomologists, ornithologists, zoologists, archaeologists, and land use planners were present. The wide region was driven by the aquatic processes and an attempt to represent entire catchments (Everard 2004). This broad boundary was refined with a series of finer scale boundaries, namely vegetation types, quaternary catchments, contours, and political boundaries. This finer scale boundary was then matched to the closest cadastral, or land parcel, boundary. All spatial data for this project were managed with a geographic information system (GIS: ArcInfo ver. 7 and ArcView ver. 3, ESRI, California).

\section{Planning units and protected areas}

Planning units are spatial, mapped boundaries used in conservation assessments (Pressey and Logan 1998). They subdivide the landscape into building blocks, each of which can be quantitatively assessed for the biodiversity patterns or processes it contains, or forms part of. We used cadastral boundaries as planning units, since this is commonly the unit used for land purchase or sale. Within the GIS, the planning domain boundary map and the protected area boundaries map were both derived from the planning unit map. Protected areas were divided into two categories (Fig. 2). Type 1 protected areas are owned and run by the state, province, or a local authority, and conservation legislation is strong, e. g., national parks and provincial reserves; Type 2 protected areas are on public or private land managed for conservation as well as other land uses, and conservation legislation is weak or nonexistent, e.g., conservancies and private nature reserves (Lombard et al. 2003). Planning unit sizes ranged from approximately 1-11,000 ha (Type 1 Protected Areas) and from $<1-8351$ ha for all other units.

\section{Biodiversity patterns}

We used vegetation pattern as a surrogate for biodiversity pattern. The vegetation map was compiled from Cowling and Heijnis (2001) and Vlok and Euston-Brown (2002). Sixty-four vegetation types occur in the planning domain, 
Fig. 2. The location of the Gouritz planning domain in South Africa (inset). The enlarged map shows perennial rivers, and existing protected areas (Types 1 and 2) that lie in two east-west axes mainly along the two mountain ranges. Broadly speaking, the Nama-Karoo biome lies to the north of the northern mountain range, and the fynbos biome lies between the southern mountain range and the sea, as well as on the mountains. The Succulent Karoo biome lies mainly between the two mountain ranges, as thicket vegetation tracks most river courses and coastal areas. The forest biome enters the planning domain only in the south-east.

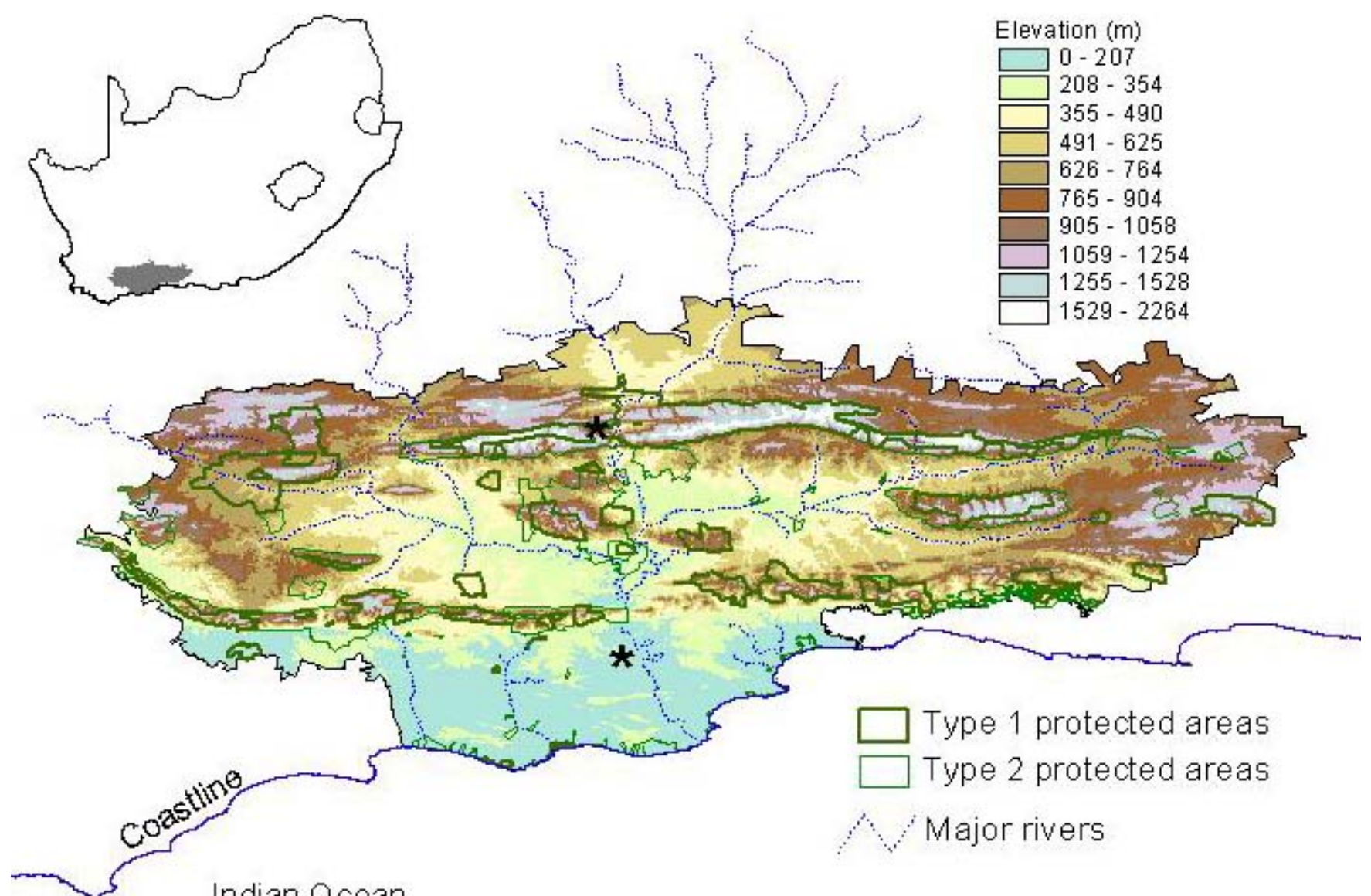

thirty of which are endemic to it (Lombard et al. 2004).

In order to determine the ecosystem status of each vegetation type, we calculated its amount of transformation using LANDSAT TM (Rouget et al. 2003), and the degree to which its conservation target has been met in Type 1 and 2 protected areas. Vegetation targets are percentages of the original extent of vegetation types that are required for formal protection, in Types 1 and 2 protected areas, and they are set using biodiversity richness and endemism data, e.g., species plots. We used the targets developed by Cowling et al. (2003a) and Rouget et al. (2006), and these ranged from $10-100 \%$ of the pretransformation extent. To calculate the ecosystem status, we plotted each vegetation type against two axes. The $\mathrm{X}$-axis is the percentage of the target that has already been met in Types 1 and 2 protected areas. Hence, a vegetation type with a target of 1000 ha, but with 400 ha already under protection, has an X-axis value of 40(\%). Any 
transformation in the protected area does not contribute to targets. The Y-axis is the percentage of remaining untransformed, unprotected vegetation that is required to meet currently unmet targets. Therefore, in the example above, the unmet target is 600 ha. Should this be all that is left in an untransformed state of this vegetation type, the Yaxis value would be 100(\%). Using the position of each vegetation type on the graph, we defined five categories of ecosystem status: (1) critically endangered, i.e., vegetation types can endure no further transformation if targets are to be met; (2) endangered, $<50 \%$ of targets are currently met and $>40 \%$ of remaining, untransformed land is required to meet targets; (3) vulnerable, $<50 \%$ of targets are met and $<40 \%$ of remaining, untransformed land is required to meet targets; (4) least threatened, $>50 \%$ of targets are met and $<40 \%$ of remaining, untransformed land is required to meet targets; and (5) monitoring, targets are currently met. This approach is similar to the one used to list threatened ecosystems under the South African Biodiversity Act (Act No. 10 of 2004: National Environmental Management: Biodiversity Act).

\section{Biodiversity processes and corridors}

Processes for the planning domain were mapped at a scale of 1:250,000 at the expert workshops previously mentioned. We used vegetation maps and geomorphic characteristic maps to spatially delineate nine processes, using simple cartographic overlay (Table 1). Geomorphic characteristics included quartz patches (Driver et al. 2003), altitude, and rivers. No modeling techniques such as least cost path analyses were used because we did not consider trade-offs against other land uses in the corridor design. These trade-offs were considered in a following step where implementation categories were assigned.

Once biodiversity processes had been matched to vegetation or landform boundaries, final process boundaries were matched to the closest planning unit boundary. Although only one broad aquatic process was identified (P1 - the north-south Gouritz River corridor), all aquatic processes were a major determinant in the planning domain definition. These processes are linked to river and wetland systems, and we attempted to represent entire catchments, where possible, as well as examples of both inland and coastal river systems. The other eight processes (P2 - P9) are all terrestrial and are described in detail in Lombard et al. (2004). These biodiversity processes (P1-P9) form the conservation corridor network of the planning domain.

\section{Agriculture}

Outside Type 1 and 2 protected areas, farming with livestock and cultivated crops are the major land uses in the planning domain. Different types of farming practices were delineated on 1:250,000 map sheets at expert workshops attended by members of the Department of Agriculture and nature conservation managers. Each farming practice was assigned to one of five classes with respect to its income generation potential, ranging from high to very low. This information will allow future conservation plans to identify farms that are likely to benefit from conservation incentives, and farms that would incur too much of an opportunity cost if current lucrative farming practices were stopped.

\section{Implementation categories}

Using biodiversity pattern and process information, and farming income generation potential maps, we plotted each planning unit on a graph, and assigned it to an implementation category of one to five based on its position on the graph. Planning units with similar biodiversity values and farming income potentials were thus allocated to particular implementation categories that have a suite of actions and instruments available to them to achieve conservation goals, for example, purchase for conservation, biodiversity agreements, megaconservancy networks, community projects, and biodiversity projects (see Table 2 ).

Although these implementation categories are appropriate for most of the planning domain, the coastline is severely threatened by coastal developments, e.g., urbanization, golf developments, polo fields. We have not included a separate analysis for this region because the $\mathrm{X}$-axis would measure the nonfarming income derived from these developments. A separate analysis is currently being conducted for the coastline at provincial level, with extensive stakeholder input (Garden Route Initiative, http://www.gri.org.za). Given the difficulties encountered in integrating outputs of different biodiversity plans undertaken for the same region, the decision was made to exclude the area of overlap from the current analysis. 
Table 1. Nine broad-scale biodiversity processes, and their spatial surrogates, in the Gouritz planning domain. All spatial boundaries were matched to the closest planning unit boundary. The processes form the corridor network. Further details can be obtained from Lombard et al. (2004).

\begin{tabular}{ll}
\hline \hline Process \\
\hline P1 & $\begin{array}{l}\text { Migration and exchange across macroclimatic gradients between } \\
\text { inland and coastal biotas, north and south biotas, and upland- } \\
\text { lowland biotas, providing dispersal opportunities in the event of } \\
\text { environmental change; maintenance of fresh water flow, water } \\
\text { quality and quantity, flood control, and estuarine integrity }\end{array}$
\end{tabular}

quality and quantity, flood control, and estuarine integrity
Spatial component

Method of

identification
P2 Geographic diversification of plant and animal lineages;

and migration of biota, especially far-ranging animals such as birds

P4 and leopards; maintenance of natural fire regimes (many fynbos species are fire-driven); generation and maintenance of perennial fresh water for the lowlands (the mountains are important water catchment regions to retain surface and underground water sources)

\author{
Riverine corridors All planning units Rivers \\ that intersect with \\ the North-South \\ Gouritz River \\ main stem, and its \\ two sources in the \\ north, the Dwyka \\ and Gamka Rivers
}

Macroclimatic gradients of westeast mountain chains

The west-east corridor across the mountain fynbos complex vegetation types, along the northern mountain chain (P2), and southern mountain chain (P4)

Quartz patches and Delineated on base associated succulent maps at expert workshops

Quartz patches lineages (there is a high turnover of species within and among these heterogeneous patches); seed dispersal (quartz patches and associated succulent vegetation are hotspots of botanical diversity and occur as stepping-stones along a northwest to southeast gradient in the western Little Karoo, providing a gradient of changing species - they are not continuous, but are linked to one another via processes such as seed dispersal, for example, by leopard tortoises)

P5 Maintenance of dispersal and diversification of the distinctive coastal biota, most of which are restricted to this narrow, linear zone; inland movement of marine sands and associated soil development within coastal dunes and sand movement corridors; maintenance of plant succession processes associated with the primary dune systems; coastal wetlands performing flood control and water filtration thereby enhancing estuarine integrity; intact coastal regions provide protection against storm events and sea-level rise in response to global warming

P6 Representation of the biological gradients, i.e., north-south, upland-lowland, and east-west macroclimatic gradients, within the biogeographically distinct Gouritz water catchment (intact gradients promote the long-term maintenance of ecological and evolutionary processes such as migration, diversification, and adaptation to climate change along drainage basins that support thicket vegetation).

P7 Plant and animal dispersal associated with the biodiversity of the Renosterveld of the coastal forelands (this is not catered for in any of the other corridors - the vegetation of the region is highly fragmented, mainly by wheat fields, but many small patches remain along the hilltops and these enable seasonal migration of some fauna and act as important refugia for geophytes and small succulent plants, many of which are highly localized endemics) vegetation

\author{
Coastal corridors Coastal vegetation Coastline \\ types within a two Vegetation types \\ $\mathrm{km}$ coastal \\ corridor from the \\ west to the east of \\ the planning \\ domain.
}

\author{
Vegetation types \\ Altitude data

(1)


Seasonal movement patterns of pollinators (Cape sugarbirds and orangebreasted sunbirds are specialist pollinators of the Protea and Erica species, respectively, and track seasonal flowering patterns)

P9 Plant and animal dispersal associated with the biodiversity of the lowlands; disturbance created by, for example, grysbok and bushbuck movement and feeding, and by molerats tunnelling these processes are important for the regeneration of fynbos plants; pollination by, for example, nectarivores, which need to be able to fly across ecologically intact areas.

\author{
Proteaceous and \\ Ericacaeous \\ fynbos pollinator \\ migration routes
Proteaceous and
Ericacaeous
fynbos of uplands
and lowlands \\ Vegetation types

$\begin{array}{ll}\begin{array}{l}\text { Lowland } \\ \text { vegetation }\end{array} & \text { Lowland and } \\ \text { coastal vegetation, Rivers } \\ \text { and vegetation } \\ \text { associated with } \\ \text { east-west bands of } \\ \text { geology, and } \\ \text { north-south } \\ \text { gradients along } \\ \text { river courses. }\end{array}$

\section{Projects}

Owing to the crosscutting nature of competing land uses, institutional responsibilities, as well as ecological processes in the planning domain, it is essential that all land management practices in the area embrace the goal of ecologically sustainable land management. To facilitate this, under the umbrella of the GI we developed a suite of projects. For each project, we identified broad and fine scale biodiversity patterns and processes that need to be addressed, and how they should be addressed, as well as land use pressures that need to be mitigated, opportunities that exist, and the institutions and communities that need to be involved. We developed a total of 60 projects, which are spatially explicit and are described in detail in Lombard et al. (2004).

\section{RESULTS}

\section{Biodiversity patterns (ecosystem status)}

Figure 3 a shows the ecosystem status of vegetation types within the entire planning domain, and Figure $3 \mathrm{~b}$ maps the ecosystem status of vegetation types within the corridor network only. In general, the low lying vegetation types are more transformed, owing to fertile coastal and valley soils, and also have less protection, whereas the mountain fynbos vegetation has little transformation because it is less arable, and a lot of protection because there are no competing land uses. The ecosystem status of vegetation types thus improves with altitude and the inverse of soil depth. The four critically endangered vegetation types can tolerate no more transformation; all remaining untransformed land is required to meet targets. Five vegetation types have an endangered status, and as many as 30 are vulnerable; eleven of these have no protection in Types 1 and 2 protected areas. A further five vegetation types have status = least threatened, and 20 have their targets met in existing Type 1 and 2 protected areas, status = monitoring. Details of the vegetation types in each category are given in Lombard et al. (2004).

\section{Biodiversity processes (corridor network)}

Figure 4 spatially represents the corridor network defined by the broad-scale processes listed in Table 1. Many of the corridors overlap spatially, with a maximum overlap $=$ four. The protection and transformation statistics of the entire planning domain, and the corridors only, are shown in Figure 5. Although $20 \%$ of the planning domain is protected by Type 1 and 2 protected areas, $69 \%$ has reversible transformation, mainly natural grazing, and $11 \%$ is irreversibly transformed. This transformation lies mainly on the coastal plain. Within the corridors, $30 \%$ falls within Types 1 and 2 protected areas, $61 \%$ has reversible transformation, and $9 \%$ is irreversibly transformed.

The nine corridors identified in this study represent $58 \%$ of the planning domain, 60 of its 64 vegetation types, and $87 \%$ of the total area of Types 1 and 2 protected areas. Almost one third $(30 \%)$ of the corridor network falls within Types 1 and 2 protected areas, which meet planning domain targets for 16 vegetation types. Of the other 44 vegetation types that occur in the corridor network, 
Table 2. Description of the land use types within the five implementation categories defined in Fig. 7, and proposed actions and instruments to achieve conservation outcomes in each of these categories.

Implementation category
Description
Proposed actions and instruments
Implementing agencies

1 Land is of high biodiversity and low farming value, and should be secured for formal conservation, e.g., type 1

- Purchase for conservation (area is only or 2 protected areas. Restoration may be required

- Statutory conservation agencies

2 Land is of high biodiversity and high farming value. Many farms are adjacent to rivers and use these for irrigation. This land use is difficult to change, but those parts of the farm far away from the rivers often contain untransformed areas. Preliminary discussions indicate a high willingness among farmers to have this untransformed land managed by conservation agencies, for example, alien plant removal.

3 Land is of lower biodiversity and low farming value. Most of the planning domain is grazed and falls into thi category. Actions must be diverse and can include a mixture of land use changes, protection, or biodiversity agreements. Opportunity costs for farmers will be low, and alternative land use practices, e.g., game farming instead of small stock grazing, may be financially beneficial.

- Biodiversity agreements such as CapeNature's Stewardship Programme

- Management plans drawn up by agricultural extension officers

- Environmental branding of farming products, e.g., wines

- Reduction of biodiversity losses on cultivated land where possible, e.g., vegetation plots for "critical" vegetation types

- Conservancy formation in megaconservancy networks (Knight and Cowling 2003)

- Biodiversity agreements

- Community projects, especially for poorer areas
- Local conservation agency

- National Department of

Agriculture

- Land owners
- Local conservation agency

- National Department of

Agriculture

- National Department of

Water Affairs and

Forestry

- Land owners

- Other national institution
4 Land is of lower biodiversity and high farming value.

$5 \quad$ Identify any biodiversity patterns or processes of concern, and ensure these are dealt with by projects.
- Proceed as for Category 2 above, but as a lower priority with respect to both timing and effort.
- Projects, e.g., alien eradication, reduction of pollutants into rivers
- Gouritz Initiative
32 can meet their outstanding targets in currently untransformed, unprotected land within the corridors alone. This emphasizes the important role of the corridors in meeting pattern targets. However, the emphasis in this study was on broad-scale processes, because a focus on pattern conservation alone could foreclose on options for maintaining broad-scale processes, e.g., fences stop animal movement and some bird pollinators will not fly across transformed land. Nevertheless, we advocate that the methods used here should be augmented with pattern studies, and South Africa currently has a legal framework in place to deal with the issue of habitat loss outside of protected areas, i.e., ecosystems are given a threat status under the National Environmental Management Biodiversity Act - NEMBA, http://www.environment.gov.za).

We understand that many finer scale processes operate both within the corridors and between them. Owing to the large areas over which these corridors operate, they are in danger of becoming fragmented and interrupted by anthropogenic activities, e.g., expanding irrigated agriculture and fence construction. This in turn would lead to the breakdown of finer scale processes, e.g., seed dispersal by localized vertebrates. Consequently, we believe that the corridors form an ecological 
Fig. 3. The ecosystem status of each of the 64 vegetation types in the planning domain. In (a), the number of vegetation types in each category is listed in the legend. Note that 20 vegetation types meet their targets in protected areas (status = Monitoring), and thus all fall on the same, single symbol. Values are assigned to ecosystem status as follows: critically endangered $=4$, endangered $=3$, vulnerable $=2$, least threatened $=1$ and monitoring $=0$. These values are used to calculate the biodiversity value in Figure 7a. Below, Fig. (b) shows the distribution of the ecosystem status of vegetation types within the corridor network only.
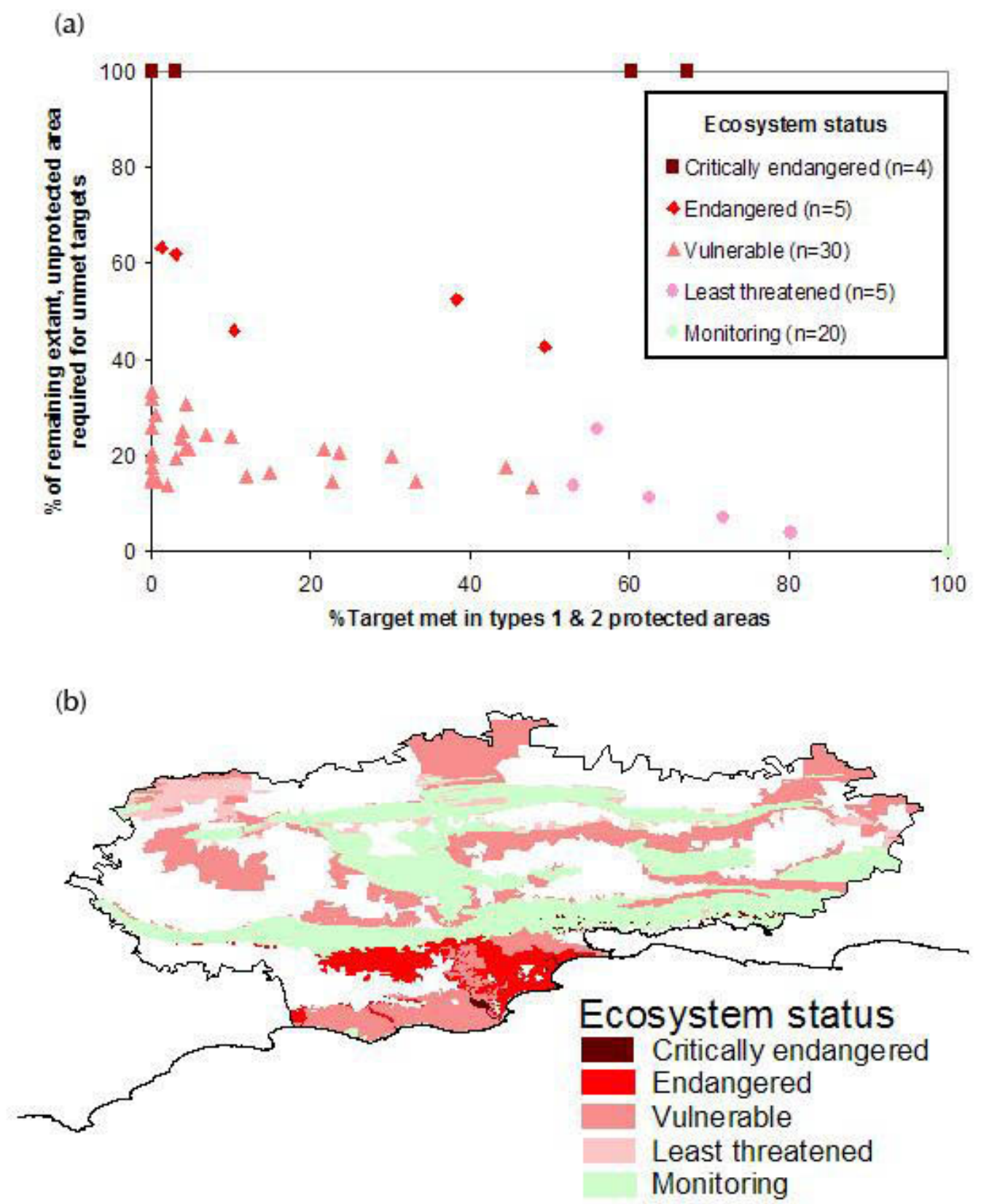
Fig. 4. The corridor network developed for the Gouritz planning domain. Corridors are defined by nine broad-scale biodiversity processes (P1-9), matched to the closest planning unit boundary. Note that P9, i.e., lowland vegetation and finer-scale processes, occurs at scales finer than can be plotted in this figure.

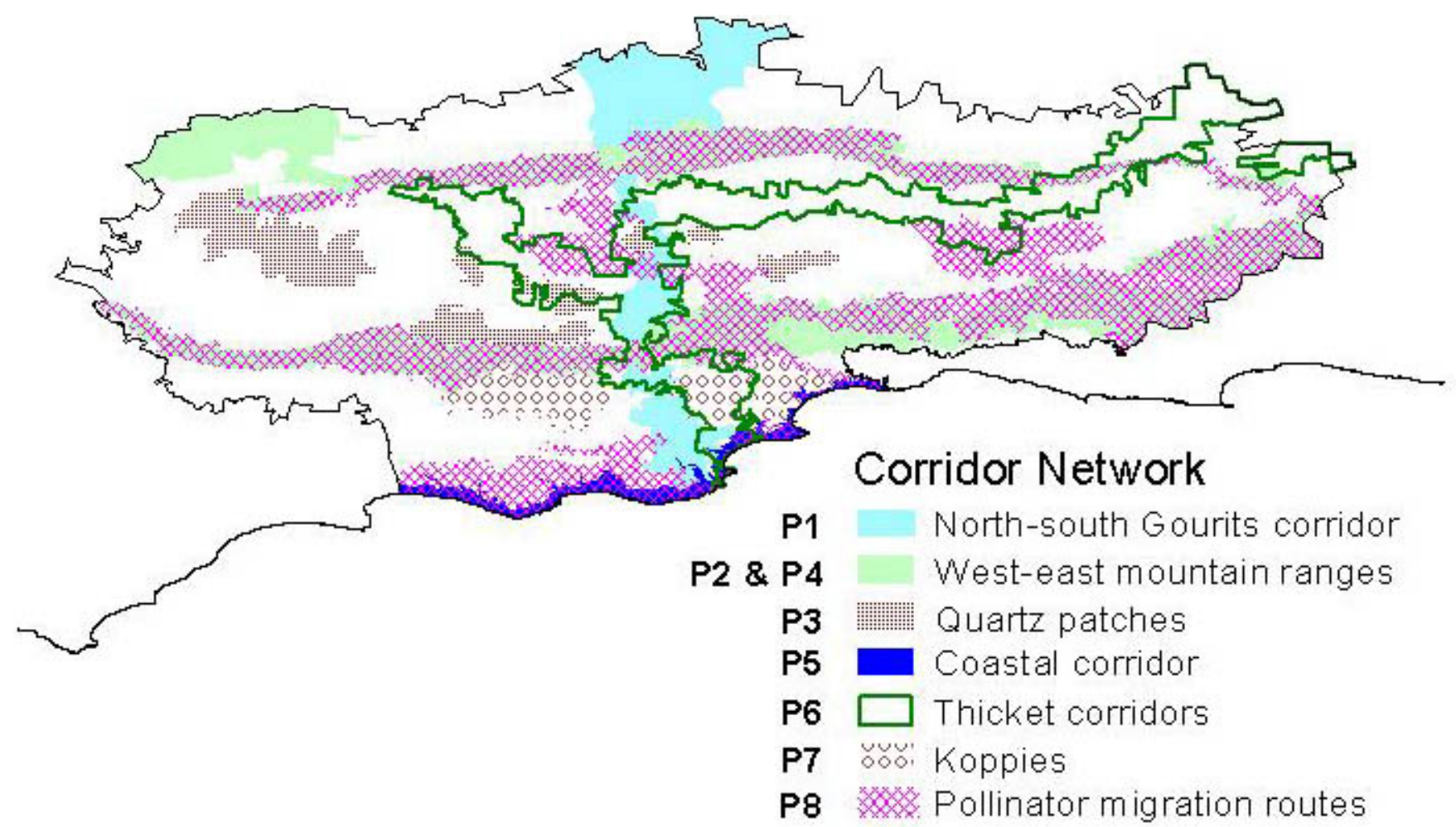

framework upon which the ecological health of the Gouritz planning domain depends, and that they need to be integrated into provincial and regional planning frameworks before they become too compromised to function effectively.

\section{Agriculture}

Farming practices within the corridor network include grazing, mostly in the Succulent Karoo between the mountain ranges, and dry land wheat, mainly on the coastal plain. Irrigated cultivation is limited to the watercourses and their associated alluvial soils because of the low rainfall. The income that is potentially generated from the different farming practices within the corridors is mostly low (Fig. 6). Only 5\% of the corridor area has higher income farming practices, as a result of dairy, lucerne, or alfalfa, fruit and hops, whereas $36 \%$ receives a low income from livestock farming practices, including ostriches grazing on dry lands.

\section{Implementation categories}

Table 2 describes the possible conservation actions and instruments that can be used to achieve ecological sustainability within the corridor network, and indeed within all agricultural landscapes in the planning domain. The table should be viewed in conjunction with Figure 7 . Table 2 is by no means exhaustive, but serves to demonstrate that different actions and instruments are required to achieve sustainable land use practices, depending on what the biodiversity values are, and what the competing land uses are. If one can map and value 
Fig. 5. The percentage areas of different land uses in the entire Gouritz planning domain, and in the corridor network only. Types 1 and 2 protected areas are described in the text. Type 3 protected areas include game farms, state land, or proposed conservation areas.

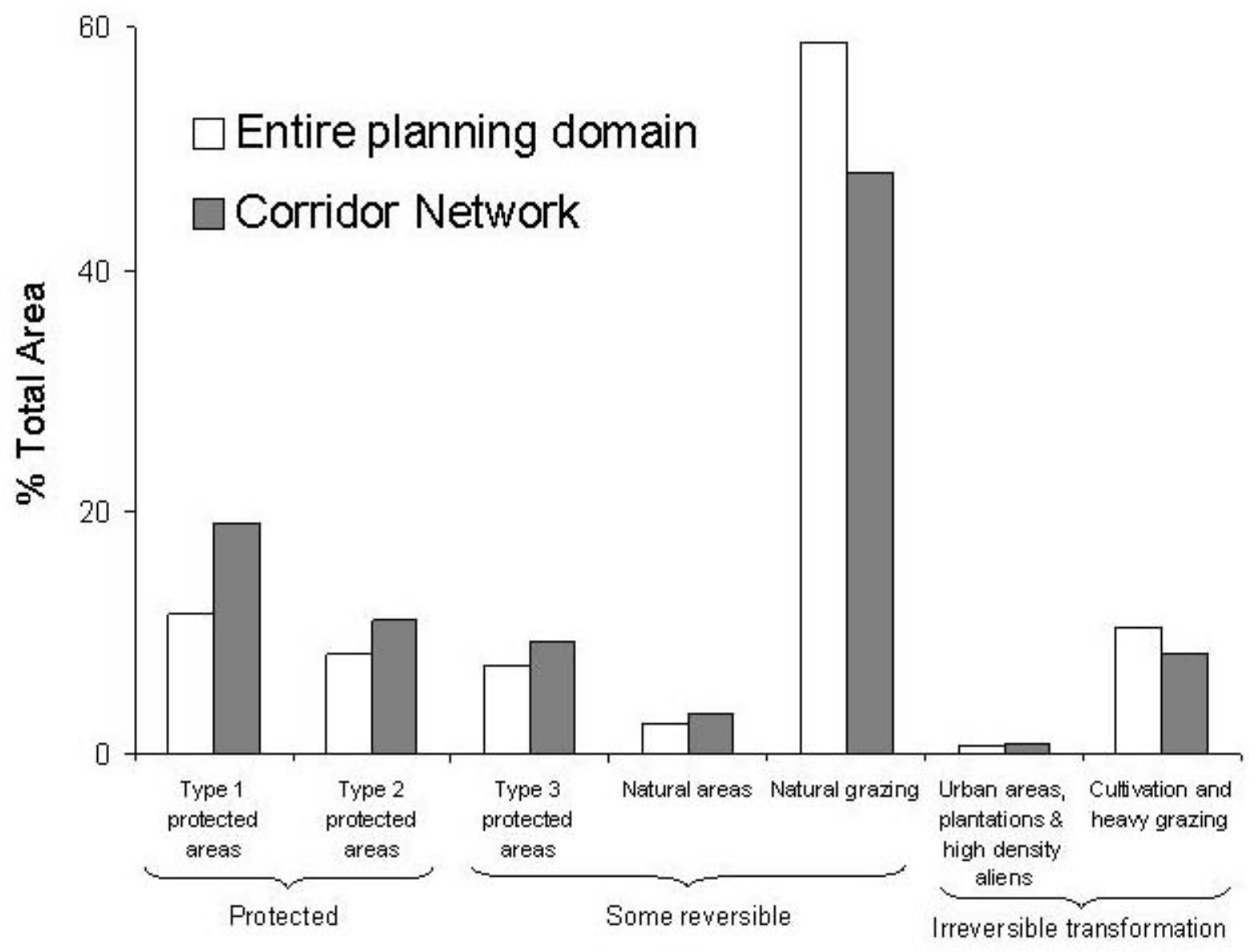

Land Use

biodiversity and these land uses, one can adopt more effective conservation strategies.

Owing to time and budget constraints, this study was not able to undertake a full assessment of opportunity costs and was limited to estimating farming income generation potential. Further studies could benefit from data generated by Egoh et al. (2010), who made considerable progress with valuing ecosystem services in the area.

\section{DISCUSSION}

The aim of our study was to design conservation corridors in a region dominated by production landscapes. Previous experience, however, has shown that systematic conservation planning methods and products need to be embedded in an operational model if they are to be implemented effectively (Knight et al. 2006b). The model in Figure 1 demonstrates that a conservation corridor design is simply the product of step one, the biophysical assessment (Knight et al. 2006a). The ultimate goal of the planning process should be the 
Fig. 6. The distribution of farming income generation potential within the corridor network.

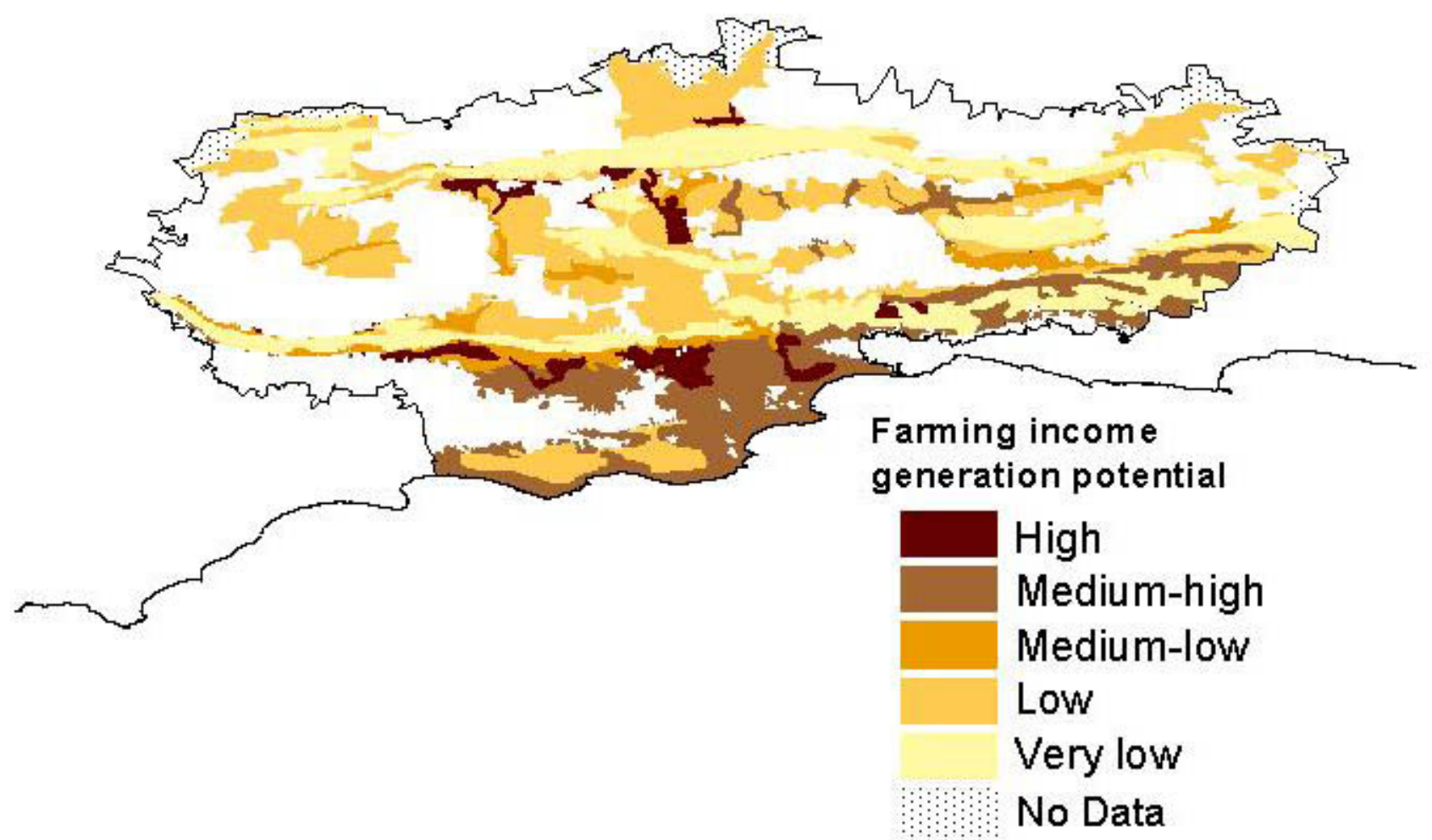

establishment of a robust learning institution (Turner and Berkes 2006) that practices adaptive governance (Folke 2007), and is able to implement conservation planning products in its region of governance. Mindful of this goal from the outset, we embedded our research within the GI and attempted to apply the model to our study. Below we discuss the phases of the model and how we addressed them.

\section{The assessment phase}

We conducted both biophysical and social assessments for the planning region. The biophysical assessments used both empirical data, i.e., vegetation pattern maps, and expert data, i.e., biodiversity processes, whereas the social assessments used expert knowledge only, to categorize farming practices by level of income derived. Both of these assessments were regional in scale (X-axis, Fig. 1), served to inform and involve all major stakeholders in the region (left-hand Yaxis, Fig. 1), and set goals for representation of biodiversity patterns and processes (right-hand Yaxis, Fig. 1).

Our focus on using experts to delineate processes and agricultural potential was driven by project time and budget constraints. It took only a few days of expert workshops to derive a great deal of spatially explicit information, and was extremely cost efficient. It also served to engender buy-in from all the regional and local authorities and implementation agencies, all of whom attended the workshops; both researchers and managers were present. Despite the possible biases that experts can bring to a planning process, we believe that the wide coverage of areas of expertise and institutional interests encompassed by the experts mitigates most of these biases. The diversity of knowledge systems involved in the planning process provides part of the foundation for 
building the institutional resilience (Gadgil et al. 2003, Olsson et al. 2006) and the social capital (Pretty 2002) required for comanagement.

As is typical with these kinds of (donor-) funded projects, insufficient resources and time were allocated for adequate biophysical and social assessments. Our biophysical assessment benefited from the availability of many previous spatial research outputs, but no appropriate socioeconomic information was available to feed into our social assessment. In addition, because the project funding was allocated to only one implementing agency, an institutional assessment was not part of the project's terms of reference. Consequently, we conducted only a rudimentary social assessment, and were unable to address land values such as rural livelihoods, attachment to land, etc.

\section{The strategy development phase}

\section{Planning products}

We considered both the opportunities and constraints in developing an implementation strategy for the planning domain (Fig. 7a). This strategy delivered a series of products that addressed both the "where" and the "how" of conservation actions, because a major stumbling block in mainstreaming conservation assessment products is the lack of practical recommendations on "how" to implement effective conservation actions (Knight et al. 2006a), or framed another way, how to spend limited resources (see Wilson et al. 2007). For example, Figure 7a shows that only $3.5 \%$ of the corridor network is recommended for direct purchase by conservation organizations, while other actions and instruments are required for the remaining network (Table 2 ).

Our products included: (1) a map of implementation categories (Fig. 7b) with an accompanying table (Table 2) of the actions and instruments that can be used to achieve conservation outcomes in the corridor; (2) a map of protected area consolidation, linking existing protected areas within the corridor network; (3) a map of management units with areaspecific details on ecological process management, consolidation opportunities, tourism opportunities, and land use pressures, both inside and outside the corridor network; and (4) a series of 60 area-specific projects addressing sustainable land use practices within the whole planning domain (see Lombard et al. 2004 for these additional products). As the model in Figure 1 illustrates, these products moved us from the assessment phase into the planning phase by serving as inputs for strategy development, and addressed finer landscape scales than the regional assessments.

\section{Implementation strategy}

The implementation strategy was quite simple: CapeNature was the institution that had commissioned the project and they were the lead implementing agency. Only CapeNature was thus mandated and funded to implement the planning products and recommendations, which were developed for their specific needs and management structures. Later is this discussion, we outline the disadvantages of this implementation strategy.

To date, however, the planning products have guided at least five key actions within GI planning domain: (1) CapeNature uses the corridor design for guiding protected area expansion and stewardship programs; (2) the Department of Agriculture has aligned their alien-clearing program with our recommendations; (3) the regional municipality has incorporated our products in their revised Spatial Development Framework; (4) the report has stimulated further interest in developing finer scale restoration projects in Spekboomveld and Gannaveld, as mentioned in public media such as Farmers Weekly/Landbouweekblad magazine and on local radio; and (5) our study has led to the formation of the Little Karoo Study Group, which is an informal network of researchers that responds to research needs identified by the GI Forum (Reyers et al. 2009).

We recommend that future studies expand on our products by undertaking cost-benefit analyses, where land use cost efficiency $=$ expected benefits divided by costs (see Polasky et al. 2005, Naidoo and Ricketts 2006, Wilson et al. 2006, Murdoch et al. 2007). Current analyses by Herling et al. (2009) have already shown the true costs associated with the unsustainable practice of ostrich farming in the planning domain.

\section{The mainstreaming phase}

Mainstreaming involves the internalization of conservation planning products into the policies and practices of sectors that deal with land and water 
Fig. 7. The allocation of planning units to five implementation categories (a). The Y-axis is the biodiversity value of the planning unit, and incorporates a pattern and a process component, i.e. biodiversity value $=$ ecosystem status value (from Fig. 3) + number of corridors (from Fig. 4). Both values range from $0-4$ therefore the maximum value is 8 , and processes and patterns contribute equally. The X-axis gives the potential farming income from Fig. 6. Individual planning units are not shown on the graph, but their areas within the entire planning domain have been summed. Sums in parentheses reflect areas inside the corridor network only. The distribution of implementation categories within the corridor network is shown in (b). Note that category 5 does not occur within the corridor network at all.

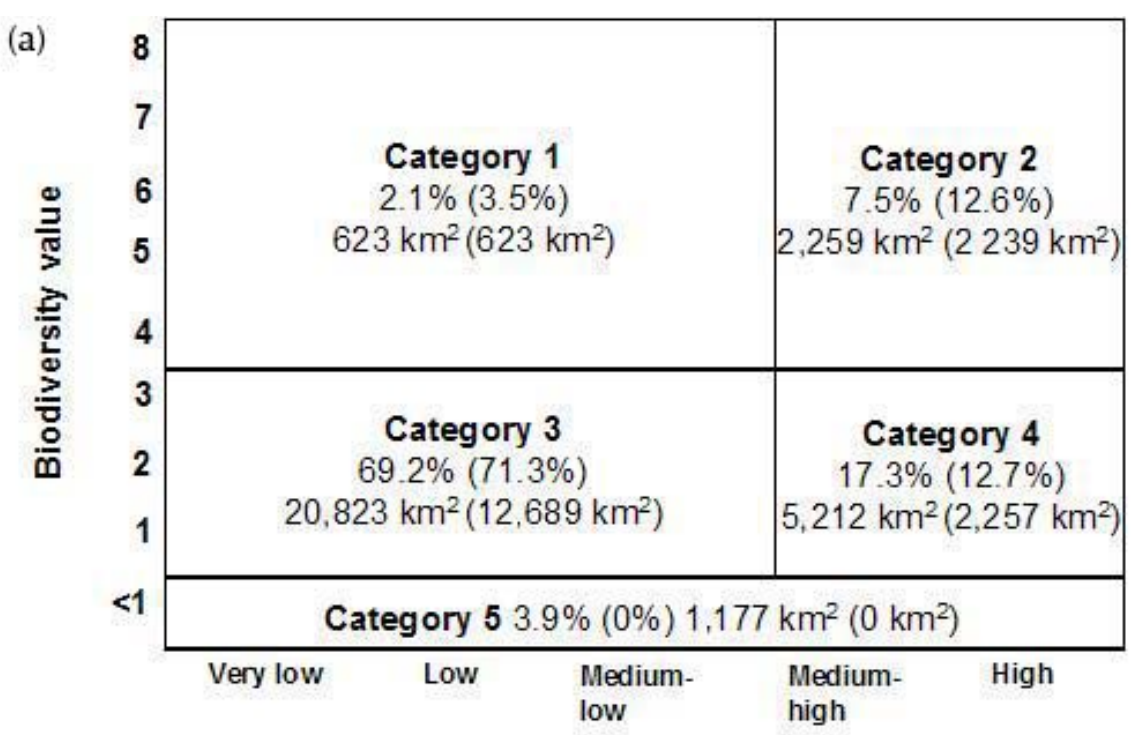

Farming income generation potential

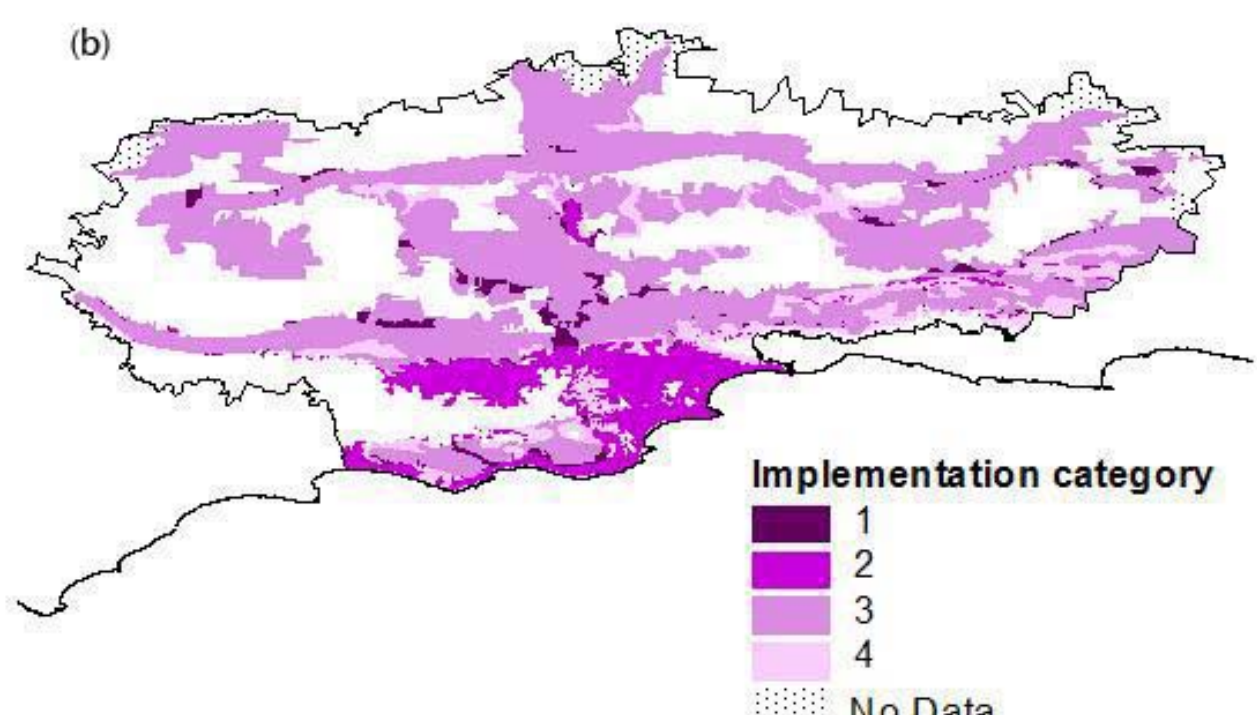


use planning (Cowling 2005). Experience in South Africa has shown that products of conservation planning assessments are more likely to be mainstreamed into legislative frameworks if they are simple, transparent, user-useful, and userfriendly (Pierce et al. 2002, Petersen and Huntley 2005). Our products were designed with this in mind and were aimed at land use managers from both conservation and agricultural backgrounds.

Owing to the large area of our planning domain $\left(\sim 33,000 \mathrm{~km}^{2}\right)$, and the broad scale over which the nine corridors operate, we aimed our products at provincial and district agencies of land use planning. These span areas of $120,000-170,000 \mathrm{~km}^{2}$ and approximately $10,000 \mathrm{~km}^{2}$, respectively. Finer scale products are required for municipal agencies, which manage land over areas in order of 1000-2000 $\mathrm{km}^{2}$.

\section{The implementation phase}

It was at this point of the conservation planning process (Fig. 1) that the first major stumbling block was reached. It resulted from a mismatch between the implementing agency's mandate, i.e., conservation, and the majority private land use in the planning domain, i.e., agriculture. The initially appointed conservation-implementing agency, CapeNature, is responsible for only $12 \%$ of the planning domain, whereas $70 \%$ is under livestock management or cultivation (Fig. 5) and thus falls under the mandate of the Department of Agriculture (DoA). We thus argue that a multistakeholder group, with strong input from the DoA, should have been tasked with implementing the GI. We also believe that it may have been wiser to use ecosystem services (sensu MA 2005) such as soil conservation and water security as the focal points of planning and management (Capistrano et al. 2005), rather than biodiversity value, because the value systems of most of the landowners are more in tune with the value system of the DoA than with CapeNature. There also seems to be incongruence between the scale of ecosystem management, at the individual farm unit, and the provincial scale of governance. To achieve congruence, an additional, finer scale of governance needs to be introduced as has been proposed by Bohensky and Lynam (2005) for catchment management institutions.
At the advent of the project, however, CapeNature was the only institution willing to facilitate the project, and the DoA was crippled by a restructuring process. As the project gained momentum, CapeNature took dedicated ownership of the project and were reluctant to hand it over to another agency. In addition, suggestions to move the project governance to a provincial or national level were barred by C.A.P.E. and CapeNature.

Given the institutional-land use mismatch described above, many of our planning products had no champion, and the implementation of the corridor network faced a series of stumbling blocks, starting with the near collapse of the GI and the disbandment of the Steering Committee. A period of realignment then began, where the C.A.P.E. Project team commissioned an independent review of the GI and appointed a small advisory group of seven people, the G7, to identify an institutional model that would be acceptable to all stakeholders. The G7 was chaired by a national nongovernmental organization and funded, again, by the CEPF. The G7 concluded that the Biosphere Reserve concept (UNESCO's Man and the Biosphere Programme, http://www.un esco.org/mab) was the model best suited to the future development of the GI, and that it should function independently from both CapeNature and the DoA. This recommendation was strongly supported by the Gouritz Forum and is currently being implemented.

\section{Lessons learned}

\section{A consensus on the vision must be established}

Although a steering committee had been constituted to oversee the GI, no real consensus was developed regarding the vision for the GI. Different stakeholders had different expectations and no specific, transparent decision was made regarding the desired products and their implementation. In addition, the steering committee was chaired by the implementing agency, and this served to further entrench the divide between their goals and those of other stakeholders. Strong leadership, representative of all stakeholders, is required to achieve vision consensus and guide implementation. In the event that vision consensus is not possible, participatory processes can provide a forum to express these differences and thus contribute to the design of 
solutions and instruments that are acceptable to all stakeholders.

\section{A detailed social assessment of appropriate institutions is required at the outset}

We believe that a comprehensive social assessment of organizational and institutional capacity, to implement the recommendations and products of the GI, should have been conducted at the outset. This would have shown that the implementing institution needs to be (a) multistakeholder, to match the mosaic of land uses, and (b) it needs to practice adaptive cooperative governance among different institutions (see Folke et al. 2005). At least as much energy should be devoted to an institutional assessment as is devoted to the biophysical assessment, and institutions at all scales, national to local, should be identified, together with their opportunities and constraints regarding the development and implementation of planning products. These products, in turn, should be specifically designed to meet the implementers' needs. This requires a detailed understanding of the day-to-day work of individuals within implementing organizations.

\section{A learning organization should be established}

The overall goal of the GI should have been the establishment of a social learning organization that would enable stakeholders to unlock their mental models, or preconceptions, regarding conservation in the GI area, agree on actions desirable for implementing the conservation strategy, and respond to feedback from interventions. This did not happen. Instead, the implementing agency and the other stakeholders talked past each other until disillusionment occurred and the GI all but collapsed. We reiterate that the implementing agency must be one that reflects the value systems of the major land owners, in this case farmers, and if possible, the conservation message should be framed in a way that resonates with them, for example, soil conservation, farm tourism, etc.

\section{Adaptive comanagement should be established}

During the course of our project, the GI steering committee failed to achieve adaptive comanagement. No attempt was made to ensure that the evaluation of interventions was fed back to the steering committee; consequently, there was no real accountability. We believe that a great deal of money could have been saved if adaptive comanagement had been the modus operandi of the learning organization from the outset, if it had been representative of the major stakeholders in the planning domain, and if a greater effort had been made to establish a strong and representative leadership. Although our operational model incorporated a participatory process, although by no means exhaustive, elite capture by the implementing agency intervened and disempowered other stakeholders. We believe that a strong participatory process is required right at the outset of similar projects, where funding agencies identify appropriate donor recipients in collaboration with all affected stakeholders.

Adaptive comanagement requires a step-wise progression from knowledge generation, awareness raising, motivation, and action (Fabricius et al. 2007). Incorporation of local expert knowledge and the formation of knowledge networks are essential first steps in mobilizing stakeholders, but adaptive comanagement also requires strong leadership and vision, the development of polycentric institutions sensu Libel et al. (2006), high levels of motivation through tangible incentives, establishing and maintaining links between culture and management, and enabling policies (Fabricius et al. 2007). The 'management' phase in Knight et al. (2006a) and Cowling et al. (2008) therefore needs to run in parallel to all other phases, with a focus on knowledge generation, trust building, awareness raising, capacity development, and motivation throughout. This on-going process prepares the system for change (Olsson et al. 2004), with empowerment as an outcome of the process (Berkes 2006). This requires long term, expert facilitation and institutional development, including conflict resolution mechanisms (Folke et al. 2005), implementation of participatory monitoring systems to assess and track social and ecological change (Armitage et al. 2008), and the involvement of all key institutions operating at several spatial scales (Dietz et al. 2003). Biodiversity and ecosystem services are essentially common pool resources and their management will benefit from the inclusion of common property management principles as advocated by Ostrom (2007). 


\section{CONCLUSION}

Despite the failures we cite above, by following the initial steps of the operational model outlined in Figure 1, we produced a series of products that are user-friendly and useful for all levels of governance, and once the Biosphere Reserve is established, these products will be available for immediate implementation. Expert knowledge was key to developing these products, because of time and budget constraints, and because stakeholders are more likely to endorse products if people they know and respect are among the experts driving the planning process. However, the GI could have saved an enormous amount of time and money: if the correct institutional model for implementation had been established at the outset, via a far more robust participatory process; if a common vision satisfactory to all stakeholders had been established; and if leadership had been responsive to feedbacks. These institutional and governance requirements are fundamental to success of any conservation efforts in production, and indeed other, land or seascapes.

Responses to this article can be read online at: http://www.ecologyandsociety.org/voll5/iss3/art7/ responses/

\section{Acknowledgments:}

We are extremely grateful to the many scientists, managers, and planners who attended our workshops and contributed significantly to development of planning products. They represented conservation agencies, the Department of Agriculture, the Department of Water Affairs and Forestry, the tourism sector, the Council for Scientific and Industrial Research, NGOs, academic institutions, museums, and independent experts. Special thanks to Marina Eilers of the Gouritz Initiative for her unending support, and Dr. Anne Lise Schutte-Vlok and Ivan Donian of CapeNature, who shared their understanding of the biodiversity and management issues within the planning domain. Taniia Strauss and Trevor Wolf were the other two members of the project team and they assisted at all stages of the project. The Critical Ecosystem Partnership Fund provided supporting grants.

\section{LITERATURE CITED}

Agrawal, A., and A. Chhatre. 2006. Explaining success on the commons: community forest governance in the Indian Himalaya. World Development 34(1):149-166.

Armitage, D., M. Marschke, and R. Plummer. 2008. Adaptive co-management and the paradox of learning. Global Environmental Change 18:86-98.

Balmford, A., G. Mace, and J. R. Ginsberg. 1998. The challenges to conservation in a changing world: putting processes on the map. Pages 1-28 in G. Mace, A. Balmford, and J. R. Ginsberg, editors. Conservation in a Changing World. Cambridge University Press, Cambridge, UK.

Barthel, S., J. Colding, T. Elmqvist, and C. Folke. 2005. History and local management of a biodiversity-rich, urban cultural landscape. Ecology and Society 10(2): 10. [online] URL: http://www.e cologyandsociety.org/vol10/iss2/art10/.

Bawden, R., I. Guijt, and J. Woodhill. 2007. The critical role of civil society in fostering societal learning for a sustainable world. Pages 133-147 in A. Wals, editor. Social learning: towards a sustainable world. Wageningen Academic Publishers, Wageningen, The Netherlands.

Berkes, F. 2006. From community-based resource management to complex systems. Ecology and Society 11(1): 45. [online] URL: http://www.ecolog yandsociety.org/vol11/iss1/art45/.

Bohensky, E., and T. Lynam. 2005. Evaluating responses in complex adaptive systems: insights on water management from the Southern African Millennium Ecosystem Assessment (SAfMA). Ecology and Society 10(1): 11. [online] URL: http: //www.ecologyandsociety.org/vol10/iss1/art11/.

Bojórquez-Tapia, L. A., L. P. Brower, G. Castilleja, S. Sánchez-Coló, M. Hernández, W. Calvert, S. Díaz, P. Gómez-Priego, G. Alcantar, E. D. Melgarejo, M. J. Solares, L. Gutiérrez, and M. Del Lourdes Juárez. 2003. Mapping expert knowledge: redesigning the Monarch Butterfly Biosphere Reserve. Conservation Biology 17:367-379.

Borrini-Feyerabend, G. 1997. Beyond fences: seeking social sustainability in conservation. 
International Union for Conservation of Nature (IUCN), Kasparek Verlag, Gland, Switzerland.

Capistrano, D., C. Samper, M. Lee, and C. Raudsepp-Hearne. 2005. Ecosystems and human well-being: multiscale assessments. Millennium Ecosystem Assessment Series Volume 4. Island Press, Washington D.C., USA.

Chalmers, N., and C. Fabricius. 2007. Expert and generalist local knowledge about land-cover change on South Africa's Wild Coast: can local ecological knowledge add value to science? Ecology and Society 12(1): 10. [online] URL: http: //www.ecologyandsociety.org/vol12/iss1/art10/.

Chetkiewicz, C.-L. B., C. C. St. Claire, and M. S. Boyce. 2006. Corridors for conservation: integrating pattern and process. Annual Review of Ecology and Systematics 37:317-342.

Costello, C., and S. Polasky. 2004. Dynamic reserve site selection. Resource and Energy Economics 26:157-174.

Cowling, R. M. 2005. The process of mainstreaming: conditions, constraints and prospects. Pages 18-25 in C. Petersen, and B. J. Huntley, editors. Mainstreaming biodiversity in production landscapes. Global Environment Facility, Washington, D.C., USA.

Cowling, R. M., B. Egoh, A. T. Knight, P. J. O'Farrel, B. Reyers, M. Rouget, D. Roux, A. Welz, and A. Wilhelm-Rechman. 2008. An operational model for mainstreaming ecosystem services for implementation. Proceedings of the National Academy of Sciences 105(28):9483-9488.

Cowling, R. M., and C. E. Heijnis. 2001. The identification of broad habitat units as biodiversity entities for systematic conservation planning in the Cape Floristic Region. South African Journal of Botany 67:15-38.

Cowling, R. M., S. M. Pierce, and T. Sandwith. 2002. Conclusions: the fundamentals of mainstreaming biodiversity. Pages 143-153 in S. M. Pierce, R. M. Cowling, T. Sandwith, and K. MacKinnon, editors. Mainstreaming biodiversity in development: case studies from South Africa. World Bank, Washington, D.C., USA.
Cowling, R. M., and R. L. Pressey. 2003. Introduction to systematic conservation planning in the Cape Floristic Region. Biological Conservatio$n$ 122:1-13.

Cowling, R. M., R. L. Pressey, A. T. Lombard, P. G. Desmet, and A. G. Ellis. 1999. From representation to persistence: requirement for a sustainable reserve system in the species rich mediterranean-climate deserts of southern Africa. Diversity and Distributions 5:1-21.

Cowling, R. M., R. L. Pressey, M. Rouget, and A. T. Lombard. 2003a. A conservation plan for a global biodiversity hotspot - the Cape Floristic Region, South Africa. Biological Conservation 112:191-216.

Cowling, R. M., R. L. Pressey, R. Simms-Castley, E. Baard, C. Burgers, A. le Roux, and G. Palmer. $2003 \mathrm{~b}$. The expert or the algorithm? - comparison of priority conservation areas identified by park managers and reserve selection software. Biological Conservation 112:147-167.

Dietz, T., E. Ostrom, and P. Stern. 2003. The struggle to govern the commons. Science $\mathbf{3 0 2}$ (5652):1907-1912.

Dinerstein, E., G. Powell, D. Olson, E. Wikramanayake, R. Abell, C. Loucks, E. Underwood, T.Allnutt, W. Wittengel, T. Ricketts, H. Strand, S. O'Connor, and N. Burgess. 2000. A workbook for conducting biological assessments and developing biodiversity visions for ecoregionbased conservation. Part 1: terrestrial ecoregions. Conservation Science Program, WWF-USA, Washington, D.C., USA.

Driver, A., P. Desmet, M. Rouget, R. Cowling, and K. Maze. 2003. Succulent Karoo Ecosystem Plan, Biodiversity Component. Technical Report No. CCU 1/03, Cape Conservation Unit, Botanical Society of South Africa, South Africa.

Egoh, B. E., B. Reyers, J. Carwardine, M. Bode, P. J. O'Farrell, K. A. Wilson, H. P. Possingham, M. Rouget, W. de Lange, D. M. Richardson, and R. M. Cowling. 2010. Safeguarding biodiversity and ecosystem services in the Little Karoo, South Africa. Conservation Biology 24(4):1021-1030. 
Everard, M. 2004. Investing in sustainable catchments. Science of the Total Environment 324 (1-3):1-24.

Fabricius, C., C. Folke, G. Cundill, and L. Schultz. 2007. Powerless spectators, coping actors, and adaptive co-managers: a synthesis of the role of communities in ecosystem management. Ecology and Society 12(1): 29. [online] URL: http: //www.ecologyandsociety.org/vol12/iss1/art29/.

Fabricius, C., R. J.Scholes, and G. Cundill. 2006. Mobilising knowledge for ecosystem management. Pages 318-324 in W. Reid, F. Berkes, T. Wilbanks, and D. Capistrano, editors. Bridging scales and knowledge systems: concepts and applications in ecosystem assessment. Island Press, Washington, D.C., USA.

Folke, C. 2007. Social-ecological systems and adaptive governance of the commons. Ecological Research 22:14-15.

Folke, C., T. Hahn, P. Olsson, and J. Norberg. 2005. Adaptive governance of social-ecological systems. Annual Review of Environment and Resources 30:441-473.

Gadgil, M., P. Olsson, F. Berkes, and C. Folke. 2003. Exploring the role of local ecological knowledge in ecosystem management: three case studies. Pages 189-209 in F. Berkes, J. Colding, and C. Folke, editors. Navigating social-ecological systems: building resilience for complexity and change. Cambridge University Press, Cambridge, UK.

Hannah, L., B. Rakotosamimanana, J. Ganzhorn, R. A. Mittermeier, S. Olivieri, L. Iyer, S. Rajaobelina, J. Hough, F. Andriamialisoa, I. Bowles, and G. Tilken. 1998. Participatory planning, scientific priorities, and landscape conservation in Madagascar. Environmental Conservation 25:30-36.

Hein, L., K. van Koppen, R. de Groot, and E. van Ierland. 2006. Spatial scales, stakeholders and the valuation of ecosystem services. Ecological Economics 57(2):209-228.

Herling, M. C., C. F. Cupido, P. J. O'Farrell, and L. Du Plessis. 2009. The financial costs of ecologically nonsustainable farming practices in a semiarid system. Restoration Ecology (6):827-836.

Knight, A. T., and R. M. Cowling. 2003. The megaconservancynetwork concept. Keeping people on the land in living landscapes. Terrestrial Ecology Research Unit Report No. 45. University of Port Elizabeth, South Africa. [online] URL: http://bgis.s anbi.org/STEP/STEP\%20MCN\%20Concept\% 20Document.pdf.

Knight, A. T., R. M. Cowling, and B. M. Campbell. 2006a. An operational model for implementing conservation action. Conservation Biology 20:408-419.

Knight, A. T., A. Driver, R. M. Cowling, K. Maze, P. G. Desmet, A. T. Lombard, M. Rouget, M. A. Botha, A. F. Boshoff, J. G. Castley, P. S. Goodman, K. Mackinnon, S. M. Pierce, R. SimsCastley, W. I. Stewart, and A. Von Hase. $2006 b$. Designing systematic conservation assessments that promote effective implementation: best practice from South Africa. Conservation Biology 20(3):739-750.

Kress, W. J., W. R. Heyer, P. Acevedo, J. Coddington, D. Cole, T. L. Erwin, B. J. Meggers, M. Pogue, R. W. Thorington, R. P. Vari, M. J. Weitzman, and S. H. Weitzman. 1998. Amazonian biodiversity: assessing conservation priorities with taxonomic data. Biodiversity and Conservation 7:1577-1587.

Libel, L., J. M. Anderies, B. Campbell, C Folke, S. Hatfield-Dodds, T. P. Hughes, and J. Wilson. 2006. Governance and the capacity to manage resilience in regional social-ecological systems. Ecology and Society 11(1): 19. [online] URL: http: //www.ecologyandsociety.org/vol11/iss1/art19/.

Lombard, A. T., T. Wolf, and N. Cole. 2003. GIS coverages and spatial analyses for the Subtropical Thicket Ecosystem Planning (STEP) Project. Terrestrial Ecology Research Unit Report No.42, Nelson Mandela Metropolitan University, South Africa. [online] URL: http://bgis.sanbi.org/STEP/S TEP GIS TERU.zip.

Lombard, A. T., T. Wolf, and T. Strauss. 2004. GIS Specialist Services, Gouritz Initiative (GI). Report for Western Cape Nature Conservation Board, South Africa. [online] URL: http://bgis.sanbi. org/gouritz/Gouritz.pdf. 
Millennium Ecosystem Assessment (MA). 2005. Ecosystems \& human well-being: synthesis report. Island Press, Washington, D.C., USA.

Maddock, A. H., and M. J. Samways. 2000. Planning for biodiversity conservation based on the knowledge of biologists. Biodiversity and Conservation 9:1153-1169.

Martin, T. G., P. M. Kuhnert, K. Mengersen, and H. P. Possingham. 2005. The power of expert opinion in ecological models using Bayesian methods: impact of grazing on birds. Ecological Applications 15:266-280.

Meir, E., S. Andelman, and H. P. Possingham. 2004. Does conservation planning matter in a dynamic and uncertain world? Ecology Letters 7:615-622.

Miller, J. R., and R. J. Hobbs. 2002. Conservation where people live and work. Conservation Biology 16:330-337.

Mucina, L., and M. C. Rutherford, editors. 2006. The vegetation of South Africa, Lesotho and Swaziland. Strelitzia 19. South African National Biodiversity Institute, Pretoria, South Africa.

Murdoch, W., S. Polasky, K. A. Wilson, H. P. Possingham, P. Kareiva, and R. Shaw. 2007. Maximizing return on investment in conservation. Biological Conservation 139:375-388.

Naidoo, R., and T. H. Ricketts. 2006. Mapping the economic costs and benefits of conservation. PLoS Biology 4(11):2153-2164.

Olivieri, S., I. Bowles, R. B. Cavalcanti, G. A. B. Fonseca, R. A. Mittermeier, and C. Rostrom. 1995. A participatory approach to biodiversity conservation: the regional priority setting workshop. Conservation International, Washington D.C., USA.

Olsson, P., C. Folke, and F. Berkes. 2004. Adaptive co-management for building resilience in social-ecological systems. Environmental Management 34(1):75-90.

Olsson, P., C. Folke, V. Galaz, T. Hahn, and L. Schulze. 2007. Enhancing the fit through adaptive co-management: creating and maintaining bridging functions for matching scales in Kristianstads Vattenrike Biosphere Reserve, Sweden. Ecology and Society 12(1): 28. [online] URL: http://www.e cologyandsociety.org/vol12/iss1/art28/.

Olsson, P., L. Gunderson, S. Carpenter, P. Ryan, L. Lebel, C. Folke, and C. S. Holling. 2006. Shooting the rapids: navigating transitions to adaptive governance of social-ecological systems. Ecology and Society 11(1): 18. [online] URL: http: //www.ecologyandsociety.org/vol11/iss1/art18/.

Orr, D. W. 2002. Four challenges to sustainability. Conservation Biology 16:1457-1460.

Ostrom, E. 2007. A diagnostic approach for going beyond panaceas. Proceedings of the National Academy of Sciences of the United States of America (PNAS) 104(39):15181-15187.

Petersen, C., and B. J. Huntley. 2005. Mainstreaming biodiversity in production landscapes. Global Environment Facility, Washington, D.C., USA.

Pierce, S. M., R. M. Cowling, A. T. Knight, A. T. Lombard, M. Rouget, and T. Wolf. 2005. Systematic conservation planning products for land-use planning: interpretation for implementation. Biological Conservation 125:441-458.

Pierce, S. M., R. M. Cowling, T. Sandwith, and K. MacKinnon, editors. 2002. Mainstreaming biodiversity in development. Case studies from South Africa. The World Bank Environment Department, Washington, D.C., USA.

Polasky, S., E. Nelson, E. Lonsdorf, P. Fackler, and A. Starfield. 2005. Conserving species in a working landscape: land use with biological and economic objectives. Ecological Applications 15 (4):1387-1401.

Pressey, R. L., M. Cabeza, M. E. Watts, R. M. Cowling, and K. Wilson. 2007. Conservation planning in a changing world. Trends in Ecology and Evolution 22(11):583-592.

Pressey, R. L., and V. S. Logan. 1998. Size of selection units for future reserves and its influence on actual vs targeted representation of features: a case study in western New South Wales. Biological Conservation 85:305-319. 
Pressey, R. L., M. E. Watts, and T. W. Barrett. 2004. Is maximizing protection the same as minimizing loss? Efficiency and retention as alternative measures of the effectiveness of proposed reserves. Ecology Letters 7:1035-1046.

Pretty, J. 2002. People, livelihoods and collective action in biodiversity management. Pages 61-86 in T. O'Riordan, and S. Stoll-Kleeman, editors. Biodiversity, sustainability and human communities: protecting beyond the protected. Cambridge University Press, Cambridge, UK.

Redford, K. H., and B. D. Richter. 1999. Conservation of biodiversity in a world of use. Conservation Biology 13:1246-1256.

Reyers, B., P. J. O'Farrell, R. M. Cowling, B. N. Egoh, D. C. Le Maitre and J. H. J. Vlok. 2009. Ecosystem services, land-cover change, and stakeholders: finding a sustainable foothold for a semiarid biodiversity hotspot. Ecology and Society 14(1): 38. [online] URL: http://www.ecologyandso ciety.org/vol14/iss 1/art38/.

Rosenzweig, M. L. 2003. Reconciliation ecology and the future of species diversity. Oryx 37:194-205.

Rouget, M., R. M. Cowling, A. T. Lombard, A. T. Knight, and G. I. H. Kerley. 2006. Designing large-scale conservation corridors for pattern and process. Conservation Biology 20:549-561.

Rouget, M., D. M. Richardson, R. M. Cowling, J. W. Lloyd, and A. T. Lombard. 2003. Current patterns of habitat transformation and future threats to biodiversity in terrestrial ecosystems of the Cape Floristic Region, South Africa. Biological Conservation 112:63-85.

Thompson, M., J. Vlok, M. Rouget, M. T. Hoffman, A, Balmford, and R. M. Cowling. 2009. Mapping land transformation in a heterogeneous environment: a rapid and cost effective approach for assessment and monitoring. Journal of Environmental Management 43:585-596.

Turner, N. J., and F. Berkes. 2006. Coming to understanding: developing conservation through incremental learning in the Pacific Northwest. Human Ecology: An Interdisciplinary Journal. 34 (4):495-513.
Vlok, J. H. J., and D. I. W. Euston-Brown. 2002. The patterns within, and the ecological processes that sustain, the subtropical thicket vegetation in the planning domain for the Subtropical Thicket Ecosystem Planning (STEP) project. Terrestrial Ecology Research Unit Report 40, Nelson Mandela Metropolitan University, South Africa. [online] URL: http://bgis.sanbi.org/STEP/STEP Biological Survey.zip.

Welp, M., A. de la Vega-Leinert, S. StollKleemann, and C. C. Jaeger. 2006. Science-based stakeholder dialogues: theories and tools. Global Environmental Change 16:170-181.

Wilson, K. A., M. F. McBride, M. Bode, and H. P. Possingham. 2006. Prioritizing global conservation efforts. Nature 440:337-340.

Wilson, K., R. L. Pressey, A. Newton, M. Burgman, H. Possingham, and C. Weston. 2005. Measuring and incorporating vulnerability into conservation planning. Environmental Management 35:527-543.

Wilson, K. A., E. C. Underwood, S. A. Morrison, K. R. Klausmeyer, W. W. Murdoch, B. Reyers, G. Wardell-Johnson, P. A. Marquet, P. W. Rundel, M. F. McBride, R. L. Pressey, M. Bode, J. M. Hoekstra, S. J. Andelman, M. Looker, C. Rondinini, P. Kareiva, M. R. Shaw, and H. P. Possingham. 2007. Conserving biodiversity efficiently: what to do, where, and when. PLoS Biology 5(9):1850-1861. [online] URL: http://www. plosbiology.org/article/info:doi\%2F10.1371\%2Fjournal. pbio.0050223. 